\title{
Analysis of the population dynamics in the "slavic world" with a special focus on Russia
}

\author{
Nina N. Loginova ${ }^{1}$, Milan M. Radovanović ${ }^{2,3}$, Anatoliy A. Yamashkin ${ }^{1}$, Goran Vasin ${ }^{4}$, Marko D. Petrović ${ }^{2,3^{*}}$, \\ Dunja Demirović Bajrami ${ }^{2,3}$ \\ ${ }^{1}$ Faculty of Geography, National Research Mordovia State University, Saransk, Russia \\ ${ }^{2}$ Geographical Institute "Jovan Cvijić" SASA, Belgrade, Serbia \\ ${ }^{3}$ Institute of Sports, Tourism and Service, South Ural State University, Chelyabinsk, Russia \\ ${ }^{4}$ Department of History, Faculty of Philosophy, University of Novi Sad, Novi Sad, Serbia
}

Received: 2019-11-23

Accapted: $2020-07-26$

Keywords:

Slavs; historical geography population trends

Russia and other Slavic ; countries

Correspondent email: m.petrovic@gi.sanu.ac.rs

\begin{abstract}
Population changes of the Russians and other Slavs are an important original indicator of demographic, economic, political and cultural analysis of over 300 million Slavic inhabitants in Central, Eastern and Southeastern Europe. The indicators are conditioned by the large number of people executed in the World War I and World War II, significant economic migrations, the disintegration of the Soviet Union, Yugoslavia and Czechoslovakia. Utilizing data from official reports, the authors proceed to analyze the demographic tendencies in order to find out the relationship between modern demographic trends and political and economic events over the past years. The results showed that economic and demographic stagnation, which favor religious and national (ethnic) ambivalence, influence strengthening of groups ethnically isolated or religiously differentiated in the observed macroregions of Eurasia. The contemporary challenges of modern society in terms of global politics (e.g. terrorism and migrations) will be more pronounced and turbulent in these areas. For these reasons, the original data represent an important segment of the study of Slavic history, demography and politics throughout the turbulent $20^{\text {th }}$ century and the beginning of the new millennium.
\end{abstract}

\section{Introduction}

Among a multitude of aspects and conditions that have shaped the history and development of Slavic countries, demographical trends have a special role to play. Based on the contemporary trends, the progress of population will surely become vitally relevant for the destiny of Slavic civilization in the future. Modern human societies become progressively aware of national heritage as an indispensable condition for its development (Mazurov \& Slipenchuk, 2016) at every level - from an individual to the national one. What is required most urgently in this context is harmonization of all the aspects that constitute the population policy, including those that come as a result of the latest processes in the modern society and may affect the demographical phenomenon itself.

The Slavic people belong to an Indo-European ethnolinguistic group who speak the various Slavic languages within Indo-European family of languages. The Slavs are the European largest ethno-linguistic group, situated mostly in the areas of Eastern, Central and Southeastern Europe, in addition to their mass migrations in Northern Asia and North America (dominantly in three Canadian provinces: Alberta, British Columbia, and Ontario) (Neyer et al., 2013). They are currently classified into East Slavs (Russians, Ukrainians, Belarusians and Rusyns/Ruthenians), West Slavs (Poles, Czechs, Moravians, Silesians, Slovaks, Kashubs and
Lusatian Serbs/Sorbs) and South Slavs (Serbs, Bulgarians, Croats, Slovenes, Bosniaks, Macedonians and Montenegrins).

As the most populous Slavic country on the globe, Russia will be on the focus of this study. The analyzed and presented demographic data of this country will focus on the following: number of inhabitants and the share of the population by national structure, dynamics of natural increase and the summary coefficient of growth by ethnic groups, national composition of the population, natural increase segments in the regions with a large share of the Russian population, population and natural increase in Russian federal districts according to the 2014 data, etc. Along the data gained from Russian resources, the demographic data from other (predominantly) Slavic countries will also be included in the paper, showing population and natural increase, birth rate, mortality and general natural increase in \%. The findings represent a real demographic image of a Slavic population in Europe on the shift between the old and the new millennium. The unfavorable economic and political situation in most of the Slavic countries accompanying to the transition from the state to a market economy, respectively the privatization of state enterprises after the era of communism, had a significant impact on the disapproving demographic situation in the observed countries. 
The aim of this article is to point the distinctions of demographic trends in Russia compared with other Slavic countries with somewhat different population tendencies, according to official data in 1950, 2010, 2014 and 2018/2019. The end of communism has changed all spheres of life of the inhabitants of the Slavic countries (former communist states). Even more, later political and social transition, even after two decades, reflected in the determining of modern demographic trends in the observed European societies. Another aim is to show that demographic processes are not so easy to understand in the essence of what is happening. General (raw) demographic coefficients are often misused in political discussions. The last aim was to trace the relationship of modern demographic trends with political and economic events of the past years. The economy cannot be developed without understanding of quantitative and qualitative changes in the population. As soon as economic relations change, there is a need to know the laws of population development. Authors will try to give a geographical picture of the demographic situation in modern European countries with a predominant population of Slavs. This approach is interesting in itself and can provide information accessible to a wide range of readers, since the data were analyzed in comparison with other historical periods and countries.

\section{The Methods}

When considering demographic indicators of the analyzed countries, two approaches were applied. The first one, which is used in the vast majority of countries, is an approach that describes the demographic trends in the analyzed countries in terms of official statistical data. Another method relies on the analysis of the historical observation of social phenomena in the observed areas.

Quantitative analysis is based on official data and vital statistics of the Russian Federal State Statistic Service ROSSTAT, conducted in different timeframes (depending of the demographic scope). All necessary demographic information was obtained by various types of population accounting (by coverage). Basically, the research was based on the use of demographic data from population censuses (especially for Russia), which were conducted throughout the country and have provided full demographic coverage. In addition, the materials of micro-censuses (sample surveys of the country's population) were used to analyze the processes of population reproduction, the demographic situation of various ethnic groups on the countries' territory and their decisions regarding the creation of a family, child birth, etc. The materials from registers (lists) were also used, and these registers contained records on all demographic events that occurred in the family on a permanent basis. Rossiyskoy Gazety (the results of the all-Russian population census in 2010) was used, as well as the data from the Population Reference Bureau as the official demographic sources for Russia and other Slavic countries. The next step was the comparison of data related to population and natural increase, together with birth rate, mortality and general natural increase of all Slavic countries. The analysis was conducted according to the data from population censuses in 1950, 2010 and 2014 and 2018/2019, provided by the Population Reference Bureau. The use of data from 1950 was determined by the fact that approximately this period marked the transition of demographic science to the modern state. There was increased attention in studying the interrelationships of demographic, social and economic factors of social development. In the post-war period, there were significant quantitative and qualitative changes in the population of European countries. Data from 2000 shows significant changes in the political, economic and social spheres of the Slavic countries. The Slavic States of Europe took a course towards the formation of social states. The goal was to ensure decent living conditions and prosperity for all citizens of the country. In 2010, market relations have exacerbated social problems and led to a decline in living standards and that was the result of the government's activities in the field of social and demographic policy. The demographic situation in many Slavic countries has become critical. Data from 2014, 2018 and 2019 marks a modern period. The changes in the management system of socioeconomic and demographic processes were summarized. Much attention is paid to demographic processes, since the population is both a participant in economic processes and a consumer of performance results, and the most important object of management in the social sphere.

The research was performed by a conventional method of demographic and statistical analysis used during the study of the characteristics and the trends of a particular population contingent. In addition to the results of the quantitative research, the findings represent some important qualitative data in order to more fully describe the tendency and characteristic of the examined countries.

\section{Result and Discussion}

The first comprehensive census of the Russian Empire was held in 1897, counting approximately 67.5 million inhabitants. Orthodox Christians constituted 69.9\%, Muslims 10.8\%, Roman Catholics 8.9\%, Protestants $4.8 \%$ and Jews $-4.0 \%$ (Rashin, 1956). The inhabitants of the Russian Empire consisted of five basic groups (divided into several categories) and the most numerous of which were the Christians, then the city population, then the officials and the court population (the nobility, administrators, governors, and the Court). The Christians had an absolute advantage in number. The native population of the Russian Federation is basically the Russian population, but during $13^{\text {th }}$ and $14^{\text {th }}$ centuries, the formation of three main branches of the Russian population began - those were: Russians, Ukrainians and Belarusians (Bruk, 1981).

The most important stage in the formation of the Russian nation was in the $14^{\text {th }}$ century when the Moscow Russia was formed, which will become the center of the gathering of the Russians and the core of the future Empire. During the $15^{\text {th }}$ and $16^{\text {th }}$ centuries, the process of state formation lasted, especially in the European regions, and in time, cultural zones were formed: North-Russian, South-Russian and Middle-Russian. All the aforementioned groups of the Russians preserved their unique customs, culture, dialect and mentality (Loginova, 2011; Weber \& Goodman, 1981).

According to the aforementioned census of 1897, the national composition of the Russian Empire was distinguished by a multitude of people, the largest numbers of which was the Russians (55.7 million or 44.5\%), the Ukrainians (22.4 million or $17.8 \%)$ and the Belarusians (5.9 million or $4.7 \%$ ). All of them were part of a unique Russian population, which therefore had approximately 83.6 million people (66.3\%). The total number of Slavs in Russia (together 
with the Russians) was about $75 \%$. In terms of population, the Jews were the second most important group with 5.2 million people or 4.0\% (Bruk, 1981; Rashin, 1956).

The first Soviet census of 1926, which covered the whole territory of the Soviet Union, showed that the number of inhabitants was around 147 million (of which 92 million lived in Russia), but 190 ethnicities and 150 languages (dialects) were registered. There were 74 million Russians in the territory of Russia, 7.9 million of the Ukrainians and 638,000 of the Belarusians. In the same time, Ukraine had 23.2 million of the Ukrainians, 2.7 million of the Russians and 75.8 thousand of the Belarusians. In the territory of Belarus, there were 4 million of the Belarusians, 383.8 thousand of the Russians and 34.6 thousand of the Ukrainians (Leasure \& Lewis, 1967; Weber \& Goodman, 1981) (Table 1). Data that presents demographic development of Russia from the 19th century was used for better understanding of the demographic tendencies of the Slavic ethnic group.

Until today, according to the national composition, the entire Russian region are North-west, Central, Centralchernozem regions, precisely at the places where the Russian state was created. The number of Russians in these areas is about $93 \%$. Since the Russians are inhabited unevenly in regions such as Chechnya, Dagestan and Ingushetia, they constitute about $4 \%$ of the population.

In the territory of Russia, the Ukrainians are mostly inhabited in the areas of Kursk, Voronezh and Rostov, in the
Northern Caucasus, Southern Ural and Siberia. The state borders of Ukraine and Russia are not in this sense the borders of population settings. By the beginning of the $20^{\text {th }}$ century, natural increase was characterized by a large number and coefficient of births and deaths (especially children), particularly in the countryside. Thus, in 1913, there were 47.8 births and even 32.4 deaths per 1,000 people. The natural increase coefficient was thus $15.4 \%$. About $25 \%$ of the newborns did not live a single year. The average age of alive was 32 years (Weiner, Teitelbaum, 2001). A natural increase in the European Russian governorates (in \%o) is presented in detail in Table 2.

The Crude Birth Rate of newborns in Russia had a slight decline from the last decade of the 19th century. There were also significant differences in the areas of the state itself. For example, natural increase was lower in the Baltic areas (Courland - 28.6\%o, Estonia - 30.2\%o, Livonia or Liflyandiya - 30.3\%o) as well as in Perm Region - 55.0\%o, in Samara Region - 57.2\%o and in Orenburg Region - 58.2\%o. Lutheran families had the smallest number of children, while the Armenians had the largest number (Rashin, 1956). The growth of the city population affected the decline in natural growth, so the increase in St. Petersburg was two times lower than in the regions of Simbirsk (currently Ulyanovsk Oblast) and Vyatka (currently Kirov Oblast). The growth was also dependent on the conditions of life and generally belonging to the social group.

At the beginning of the 20th century, the increase fell

Table 1. Number of inhabitants and the share of the population by national structure (Slavs) on the territory of the Russian Federation, $\mathrm{n}$ (in millions), \%

\begin{tabular}{crrrrrr}
\hline & 1926 & 1959 & 1979 & 1989 & 2002 & 2010 \\
\hline Whole population & 92,7 & 117,5 & 137,4 & 147,0 & 145,2 & 142,9 \\
$\%$ & 100 & 100 & 100 & 100 & 100 & 100 \\
Russians & 74,0 & 97,9 & 113,5 & 119,9 & 115,9 & 111,0 \\
$\%$ & 79.8 & 83.3 & 82.6 & 81.5 & 80.6 & 80.9 \\
Ukrainians & 7,9 & 3,3 & 3,6 & 4,4 & 2,9 & 1,9 \\
$\%$ & 8.5 & 2.8 & 2.6 & 3.0 & 2.0 & 1.4 \\
Belarusians & 0,6 & 0,8 & 1,0 & 1,2 & 0,8 & 0,5 \\
$\%$ & 0.6 & 0.7 & 0.7 & 0.8 & 0.6 \\
Source: ROSSTAT, 2020. & & & & & \\
\hline
\end{tabular}

Table 2. Natural increase in the European Russian governorates, \%o

\begin{tabular}{rccc}
\hline Period & Crude Birth Rate (CBR) & $\begin{array}{c}\text { Crude Death Rate } \\
(\text { CDR })\end{array}$ & Natural Increase \\
\hline $1867-1870$ & 49.7 & 37.5 & +12.2 \\
$1876-1800$ & 49.5 & 35.7 & +13.8 \\
$1886-1890$ & 50.2 & 34.5 & +15.7 \\
$1896-1900$ & 49.5 & 32.1 & +17.4 \\
\hline
\end{tabular}

Source: Bruk, 1981; Rashin, 1956. 
from $50 \%$ o to $43.9 \%$. The new state policy, when it comes to birth, has led to an even greater decline in growth, and therefore in 1939, we have $31 \%$. During World War II, the number dropped to $26 \%$. After the war, the coefficient was constantly falling, especially in the 1950s and 1960s, and therefore, on the 1969 census, we have a figure of $17 \%$ (Table 3). Increasing attention was paid to the quality of life and longevity, and especially to the newborn, so there were evident changes, particularly in the countryside (Ediev, 2001; Rau, Muszyńska \& Vaupel, 2013). From 1913 to 1960, the natural increase has fallen by more than two times, but also the mortality of children by 4.4 times. The mutual conditioning of the factors of the decline in natural growth and child mortality has led to the improvement of the image of the number of newborns compared to Pre-Revolutionary Russia.

The nature of changes in the way of life and the policy of birth in the Soviet Union reflected on the general natural increase coefficient, which can be seen through the mean number of born children in real time. In the new model of state policy of birth, factors of ethnic differentiation also occur.

According to the indicators from the end of the 1970-es, there was a number of 2-2.1 children in Russian families, just like Ukrainian, while in Uzbek, Turkmen, Tajikistan, Kyrgyz families this number was significantly bigger - about 5-6 children. In the Russian families, the share of families with one or two children was $93.9 \%$ in 1978 . This was especially noticeable in Moscow and St. Petersburg, where the number of Russians was over $85 \%$. Dynamics of the summary coefficient of growth by ethnic groups will be presented in detail in Table 4.

Since the mid-sixties, a natural increase in Russia has fallen up to three times, but also the mortality of children. By the end of 1991, the population of Russia was at a minimal growth, but migrations increased $(+0.11 \%)$. Since 1992, Russia's population has been declining due to the economic and political situation, so natural increase has been decreasing, and this is especially contributed by migrations. In the period from 1989 to 2010, the population of Russia reduced by 4.1 million people.

The number of Russians and other Slavs grew on the

Table 3. Dynamics of natural increase, \%o

\begin{tabular}{|c|c|c|c|c|c|}
\hline Year & Crude Birth Rate & $\begin{array}{c}\text { Crude Death } \\
\text { Rate }\end{array}$ & $\begin{array}{l}\text { Natural } \\
\text { increase }\end{array}$ & $\begin{array}{c}\text { Infant mortality } \\
\text { rate }\end{array}$ & $\begin{array}{c}\text { Summary Crude } \\
\text { Birth Rate }\end{array}$ \\
\hline $1896-1897^{\star}$ & 50.5 & 34.8 & 15.7 & 326 & 7.5 \\
\hline 1928 & 48.9 & 26.8 & 22.1 & 203 & 6.6 \\
\hline 1939 & 39.8 & 23.9 & 15.9 & 189 & 4.9 \\
\hline 1950 & 27.8 & 11.5 & 16.7 & 41.2 & 2.9 \\
\hline 1960 & 23.2 & 7.4 & 15.8 & 25.3 & 2.6 \\
\hline 1970 & 14.6 & 8.7 & 5.9 & 28.0 & 2.0 \\
\hline 1980 & 15.9 & 11.0 & 4.9 & 22.6 & 1.9 \\
\hline 1990 & 13.4 & 11.2 & 2.2 & 17.8 & 1.9 \\
\hline 2000 & 8.6 & 15.2 & -6.6 & 16.9 & 1.2 \\
\hline 2014 & 13.3 & 13.1 & +0.2 & 10.3 & 1.8 \\
\hline 2019 & 10.1 & 12.3 & -2.2 & 4.9 & 1.6 \\
\hline
\end{tabular}

Source: Population Reference Bureau, 2020.

${ }^{\star}$ Numbers refer to the European part of Russia.

Table 4. Dynamics of the summary coefficient of growth by ethnic groups

\begin{tabular}{lccc}
\hline Nationality & $1958-1959$ & $1969-1970$ & $1980-1981$ \\
\hline Russian women & 2.6 & 1.9 & 1.8 \\
Ukrainian women & 2.3 & 2.0 & 1.9 \\
Belarusian women & 2.8 & 2.3 & 2.0 \\
Kyrgyz women & 4.3 & 4.8 & 4.1 \\
Turkmen women & 5.1 & 5.9 & 4.9 \\
\hline
\end{tabular}

Source: Population Reference Bureau, 2014. 
Table 5. National composition (structure) of the population of Russia

\begin{tabular}{lrrrrrr}
\hline \multirow{2}{*}{ Nationality / National affiliation } & \multicolumn{2}{c}{ Number expressed in millions } & \multicolumn{3}{c}{$\%$} \\
\cline { 2 - 7 } & \multicolumn{1}{c}{1989} & 2002 & 2010 & 1989 & 2002 & 2010 \\
\hline The whole population & 147.02 & 145.17 & 142.86 & 100.0 & 100.0 & 100.0 \\
Russians & 119.87 & 115.89 & 111.02 & 81.53 & 80.84 & 80.90 \\
Tatars & 5.52 & 5.55 & 5.31 & 3.76 & 3.87 & 3.87 \\
Ukrainians & 4.36 & 2.94 & 1.93 & 2.97 & 2.05 & 1.41 \\
Bashkirs & 1.35 & 1.67 & 1.58 & 0.92 & 1.16 & 1.15 \\
Chuvash & 1.71 & 1.54 & 1.44 & 1.21 & 1.14 & 1.05 \\
Chechens & 0.90 & 1.36 & 1.43 & 0.51 & 0.95 & 1.04 \\
Armenians & 0.53 & 1.13 & 1.18 & 0.36 & 0.79 & 0.86 \\
Avars & 0.54 & 0.81 & 0.91 & 0.37 & 0.57 & 0.66 \\
Mordvins & 1.07 & 0.84 & 0.74 & 0.73 & 0.59 & 0.54 \\
Udmurts & 0.71 & 0.64 & 0.55 & 0.49 & 0.44 & 0.40 \\
Mari people & 0.64 & 0.60 & 0.55 & 0.44 & 0.42 & 0.40 \\
Belarusians & 1.21 & 0.81 & 0.52 & 0.82 & 0.56 & 0.38 \\
Ingush & 0.22 & 0.41 & 0.44 & 0.15 & 0.29 & 0.32 \\
\hline Source: Rossyyyyyyyyyyyyy
\end{tabular}

Source: Rossiyskoy Gazety, 2010.

Table 6. Natural increase segments in the regions of the Russian Federation with a large share of the Russian population, \%o

\begin{tabular}{|c|c|c|c|c|c|c|c|c|c|}
\hline \multirow{2}{*}{$\begin{array}{c}\text { Part of the Russian Federation / } \\
\text { Region }\end{array}$} & \multicolumn{3}{|c|}{2010} & \multicolumn{3}{|c|}{2014} & \multicolumn{3}{|c|}{2019} \\
\hline & CBR & CDR & NI & CBR & CDR & NI & CBR & CDR & NI \\
\hline Russian Federation & 12.5 & 14.2 & -1.7 & 13.3 & 13.1 & +0.2 & 10.1 & 12.3 & -2.2 \\
\hline Vladimir & 10.9 & 17.2 & -6.3 & 11.2 & 16.6 & -5.4 & 8.2 & 15.7 & -7.5 \\
\hline Voronezh & 10.2 & 15.9 & 5.7 & 10.9 & 15.7 & -4.8 & 8.5 & 14.2 & -5.7 \\
\hline Ivanovo & 10.5 & 17.0 & -6.5 & 11.3 & 16.4 & -5.1 & 7.9 & 15.8 & -7.9 \\
\hline Kaluga & 10.9 & 15.4 & -4.5 & 11.8 & 15.2 & -3.4 & 8.9 & 14.6 & -5.7 \\
\hline Kirovo & 11.9 & 15.9 & -4.0 & 12.8 & 15.1 & -2.3 & 8.8 & 14.3 & -5.5 \\
\hline Kostroma & 12.3 & 16.6 & -4.3 & 12.6 & 15.9 & -3.3 & 9.1 & 14.7 & -5.6 \\
\hline Kursk & 11.6 & 16.8 & -5.2 & 11.7 & 16.5 & -4.8 & 8.5 & 15.0 & -6.5 \\
\hline Lipetsk & 10.8 & 15.3 & -4.5 & 11.6 & 15.4 & -3.8 & 8.6 & 14.3 & -5.7 \\
\hline Nizhegorod & 11.0 & 16.4 & -5.4 & 12.0 & 15.9 & -3.9 & 7.3 & 12.7 & -5.4 \\
\hline Leningrad & 8.6 & 14.6 & -6.0 & 9.0 & 14.5 & -5.5 & 9.0 & 14.6 & -5.6 \\
\hline Novgorod & 11.5 & 18.5 & -7.00 & 11.8 & 17.4 & -5.6 & 8.7 & 16.4 & -7.7 \\
\hline Oryol & 10.5 & 16.3 & -5.8 & 11.0 & 16.4 & -5.4 & 8.1 & 15.4 & -7.3 \\
\hline Pskov & 10.6 & 19.5 & -8.9 & 11.0 & 18.5 & -7.5 & 8.5 & 16.9 & -8.4 \\
\hline Ryazan & 10.3 & 16.5 & -6.2 & 11.0 & 16.1 & -5.1 & 8.3 & 15.2 & -6.9 \\
\hline Smolensk & 10.5 & 16.8 & -6.3 & 10.8 & 16.1 & -5.3 & 7.6 & 15.1 & -7.5 \\
\hline Tambov & 9.3 & 16.4 & -7.1 & 9.8 & 16.3 & -6.5 & 7.6 & 15.0 & -7.4 \\
\hline Tver & 11.0 & 18.7 & -7.7 & 11.3 & 17.8 & -6.5 & 8.6 & 16.9 & -7.7 \\
\hline Tula & 9.5 & 17.7 & -8.2 & 10.0 & 17.1 & -7.1 & 7.6 & 15.9 & -8.3 \\
\hline Yaroslavl & 11.1 & 15.8 & -4.7 & 12.0 & 15.5 & -3.5 & 9.0 & 14.7 & -5.7 \\
\hline
\end{tabular}

Note: CBR - Crude Birth Rate, CDR - Crude Death Rate, NI - Natural Increase

Source: ROSSTAT, 2020. 
territory of Russia, especially in the period 1897-1926 (by 18 million), and then from 1926 to 1989 , for another 36.3 million people. The decline in the population from 1989 to 2002 was particularly fast and dramatic. The number of Russians fell by 4 million, Ukrainians by 1.5 million, Belarusians by 400,000 . Such a tendency with mild oscillations continued in the period from 2002 to 2010 . The average age of population also testifies to the problem of an increase, the so-called aging of the nations (Russians and Ukrainians) and the expansion of the young nations (Chechens) (Weiner \& Teitelbaum, 2001). Thus, in the most recent period of Russian history, the number of Slavs fell by almost 12.1 million (Russians - 8.9, Ukrainians - 2.5 and Belarusians - 700,000) (Table 5).

This situation has its explanation due to three main historical factors. The first factor is related to the natural increase of an ethnic group. The second one is related to the processes of national (ethnic) self-knowledge, and the third factor is internal migration. Thus, there is a decline in the population in the areas where the Russians are the majority. Particularly strong natural increase is found in the territories where the Russians are a minority (Tyumen Region) or the example of the City of Moscow, which has received a significant number of inhabitants due to migrations. Regions with weaker natural increase and the highest percentage of the Russian population are the following: Pskov, Tula, Tver, Tambov and Novgorod, with $-7-5 \%$ or $-0.7-0.5 \%$ per year. The share of Russians in these regions is $87-95 \%$ approximately (Table 6).

According to the results from 2010, in Russia, households that consist of two members prevail with $62 \%$ at Belarusians, $59 \%$ at Ukrainians and $41 \%$ at Russians. From the general picture (number) of households from families with more than two members, $66 \%$ have one child, $27 \%$ have two children, and $7 \%$ have three and more children. The largest percentage of families with one child is at Belarusians (74\%), Ukrainians (71\%) and Russians (69\%). The number of families with three or more children is very small: Ukrainians and Belarusians (4\% each) and Russians (5\%). The number of families with only one person is quite large: $15 \%$ of Belarusians, $13 \%$ of Ukrainians and $10 \%$ of Russians. According to the 2010 data, the higher natural increase was in the federal republics of Chechnya, Ingushetia, Dagestan and Tuva. The people of the Caucasus have a significant number of families with four or more persons. The share of families with small children ranges from $55 \%$ to $81 \%$ (Rossiyskoy Gazety, 2010). These figures described changes in the family structure and family typology of the Slavic population: there were more single people, legally unregistered marriages, families with one child, and families with one parent. In this case, the figures demonstrated the concept of "egalitarian family development". It also recognized that sexual relations go beyond strict family boundaries, the birth of children is planned and strictly controlled, the value of children changes, marriages and births are postponed, spouses become equal and specialization in marriage is blurred. These figures emphasized that the increase in life expectancy leads to the fact that the process of reproduction becomes more economical. The number of children in families is rapidly decreasing, and there are more and more single people. This dynamic is clearly observed in Slavic families and in Slavic countries, where the process of reproduction is "fading". This is clearly visible if childbearing by ethnic group is compared. Natural increase in areas of the Russian Federation with less than $40 \%$ of the Russian population (in \%o) will be presented in detail in Table 7.

Since demographics are primarily interested in the reproductive function of the family, and it is changing in front of our eyes (especially among the Slavic population), figures that characterize this function in various ethnic groups have been shown. In the period 2002-2010, the population in the Russian Federation has dropped by $1.6 \%$, and the number of the Slavs is particularly decreasing: $4.2 \%$ of Russians, $34.5 \%$ of Ukrainians and $35.5 \%$ of Belarusians. On the other hand, the number of ethnic Muslims is slightly

Table 7. Natural increase in areas of the Russian Federation with less than $40 \%$ of the Russian population, \%o

\begin{tabular}{lrrrrrrrrr}
\hline \multirow{2}{*}{ Parts of the Russian Federation } & \multicolumn{3}{c}{2010} & \multicolumn{3}{c}{2014} & \multicolumn{3}{c}{2019} \\
\cline { 2 - 10 } & CBR & CDR & \multicolumn{1}{c}{ NI } & CBR & CDR & NI & CBR & CDR & NI \\
\hline Russian Federation & 12.5 & 14.2 & -1.7 & 13.3 & 13.1 & +0.2 & 10.1 & 12.3 & -2.2 \\
Bashkortostan & 13.7 & 13.4 & +0.3 & 14.9 & 13.1 & +1.7 & 10.4 & 12.2 & -1.8 \\
Dagestan & 18.6 & 5.6 & +13.0 & 19.1 & 5.5 & +13.6 & 14.7 & 4.7 & 10.0 \\
Ingushetia & 25.3 & 4.0 & +21.3 & 20.4 & 3.4 & +17.0 & 15.9 & 2.9 & 13.0 \\
Kabardino-Balkaria & 15.0 & 9.5 & +5.5 & 15.7 & 8.8 & +6.9 & 11.5 & 8.2 & 3.3 \\
Kalmykia & 14.6 & 10.1 & +4.5 & 14.2 & 10.0 & +4.2 & 10.3 & 9.4 & 0.9 \\
Tuva & 27.2 & 10.9 & +16.3 & 25.3 & 10.9 & +14.4 & 18.9 & 8.3 & 10.6 \\
Chechnya-Ichkeria & 28.6 & 5.2 & +23.4 & 24.0 & 4.9 & +19.1 & 11.0 & 9.0 & 2.0 \\
Sakha-Yakutia & 17.2 & 9.4 & +7.8 & 17.8 & 8.6 & +9.2 & 13.2 & 7.8 & 5.4 \\
Tatarstan & 13.4 & 12.4 & +1.0 & 14.9 & 12.6 & +2.3 & 11.0 & 11.0 & 0.0 \\
\hline
\end{tabular}

Note: CBR - Crude Birth Rate, CDR - Crude Death Rate, NI - Natural Increase

Source: ROSSTAT, 2020. 
Table 8. Population and natural increase in the Russian Federation and its federal districts (FD) according to the 2014 data

\begin{tabular}{lcccc}
\hline \multicolumn{1}{c}{ Region } & Population & $\begin{array}{c}\text { Crude Birth } \\
\text { Rate }\end{array}$ & Crude Death Rate & Natural increase \\
\hline Russian Federation & 146267,3 & 13.31 & 13.08 & +0.23 \\
Central FD & 38951,5 & 11.44 & 13.61 & -2.17 \\
North-West FD & 13843,5 & 12.30 & 13.28 & -0.97 \\
Volga FD & 29715,4 & 13.40 & 13.95 & -0.55 \\
South FD & 14003,8 & 12.82 & 13.34 & -0.52 \\
North-Caucasian FD & 9659,0 & 17.26 & 8.04 & +9.22 \\
Ural FD & 12275,8 & 15.13 & 12.39 & +2.75 \\
Siberian FD & 19312,1 & 14.72 & 13.26 & +1.46 \\
Far East FD & 6211,0 & 14.11 & 12.61 & +1.50 \\
Crimean FD & 2294,8 & 12.73 & 14.95 & -2.22 \\
\hline
\end{tabular}

Source: ROSSTAT, 2020.

increasing. Thus, according to the 2010 results, their number was 14.9 million (10.4\%), compared to the data from 2002 when they were 14.4 million (10\%) (Rossiyskoy Gazety, 2010). The North Caucasus republics especially had problems with migrations and poor living conditions. Orthodox peoples often assimilate with the Russians (e.g. Chuvash, Udmurts, Mari people, Mordvins and Karelians). As the number of Russians fell by $4.2 \%$, the number of Tatars fell by $4.4 \%$, the Bashkirs by $5.3 \%$, the Chuvash by $12.3 \%$, the Mordvins by $11.7 \%$, the Udmurts by $13.3 \%$ and the Mari people by $9.4 \%$ (Loginova, 2011). In terms of the majority population, the largest cities that remained populated with Russians are Moscow (87\%) and St. Petersburg (80.1\%). The change in the population and natural increase in 2014 had 43 parts (regions and 18 republics). Other 42 parts marked a fall. The number of inhabitants increased in four of total nine Russian federal districts: North Caucasus, Ural, Siberian and Far East (Creighton, 2014) (Table 8).

The modern situation in Russia is connected with two main current tendencies: stable increase of the level of birth rate and migration of foreign population. The number of residents of the Russian Federation in 2014 was about 143.7 million people - about $70 \%$ live in urban areas and $30 \%$ in the countryside. The growth of the Russian population has been observed since 2009 and it increased both at the expense of significantly decreased natural losses, and as a result of the progressive migratory flow (Goldstone, Kaufmann, \& Toft, 2012; Lović Obradović, Babović, \& Shpak, 2016). Moreover, the Russians are absolutely the largest Slavic community of over 150 million people worldwide, which represents circa one half of a total number of the Slavs in Eurasia (about 300 million).

In addition to the Russians, in this macroregion (Eurasia), there are approximate numbers of 9 million of the Serbs, 8.5 million of the Bulgarians, 6 million of the Croatians, 2 million of the Slovenians, 2 million of the Macedonians, 42 million of the Ukrainians, 10 million of the Belarusians, 45 million of the Poles, 11 million of the Czechs, 6 million of the Slovaks and 60,000 of the Sorbs (Lusatians). Orthodox Christianity is practiced by the majority of Slavs (Eastern Europe and most of the central, eastern and southern
Balkans), while the second most common religion is Roman Catholicism (mainly in Central Europe and in western parts of the Balkans). There are also substantial Protestant and Lutheran minorities (especially amongst the West Slavs), as well as Muslim Slavs, mostly inhabited in some territories of the former Yugoslavia (Mazurov \& Vartapetov, 2001).

In the last fifty years of the 20th century (period from 1950 to 2000), the number of the Slavs was generally increasing in Central and Southeastern Europe. Nevertheless, due to significant economic migrations from Poland, Czech Republic and Slovakia, West Slavs face many serious demographic challenges in their homelands (Eberhardt \& Owsinski, 1996). Most of them are immigrants in the USA, Canada, Germany and Australia. As Josipovič (2016) stated, the whole ex-Yugoslavia agonized a loss of about 5 million inhabitants involving the permanent emigration of the former guest-workers. Excluding Slovenia, and stagnating Montenegro and North Macedonia, all other Yugoslav countries have lost more or less of their population. When it comes to demographic trends in Serbia - the largest former Yugoslav republic, do not lag behind the other Slavic countries. According to Lović Obradović et al. (2016), Serbia has lately recorded a constant population decline and comparing the data from the 2011 census with previous one in 2002, a town of 311,139 inhabitants disappeared. The total fertility rate is 1.41 , which is unsatisfactory for the expanded population reproduction. With the reduction in fertility, an increase in the share of the population older than 65 years is recorded, as well as an increase in life expectancy. In this sense, there is a change in the balance of the old and the number of the active population and the increasing burden on the social fund. Nowadays, the demographic image of Serbia is characterized by depopulation processes due to the reduced fertility rates, increasing life expectancy, as well as the share of population older than 65 years. The fertility rate of the youngest fertile contingent is higher than the European average, as well as the rate of infant mortality, but significantly lower in relation to the values from previous years. Population and natural increase of Slavic countries according to censuses in 1950, 2000 and 2014 will be presented in detail in Table 9. 
The beginning of the 21 st century brought changes and a decrease in the number of Slavs in Central and Southeastern Europe. Czech Republic, Poland, Slovenia, Slovakia, North Macedonia and Bosnia and Herzegovina recorded a slight increase, and Montenegro remained at the same number, while in other countries a decline was recorded. Economic factors, migrations and poor state policy (when it comes to childbearing) are the main causes of this phenomenon (Table $10)$.

Table 9. Population and natural increase of Slavic countries

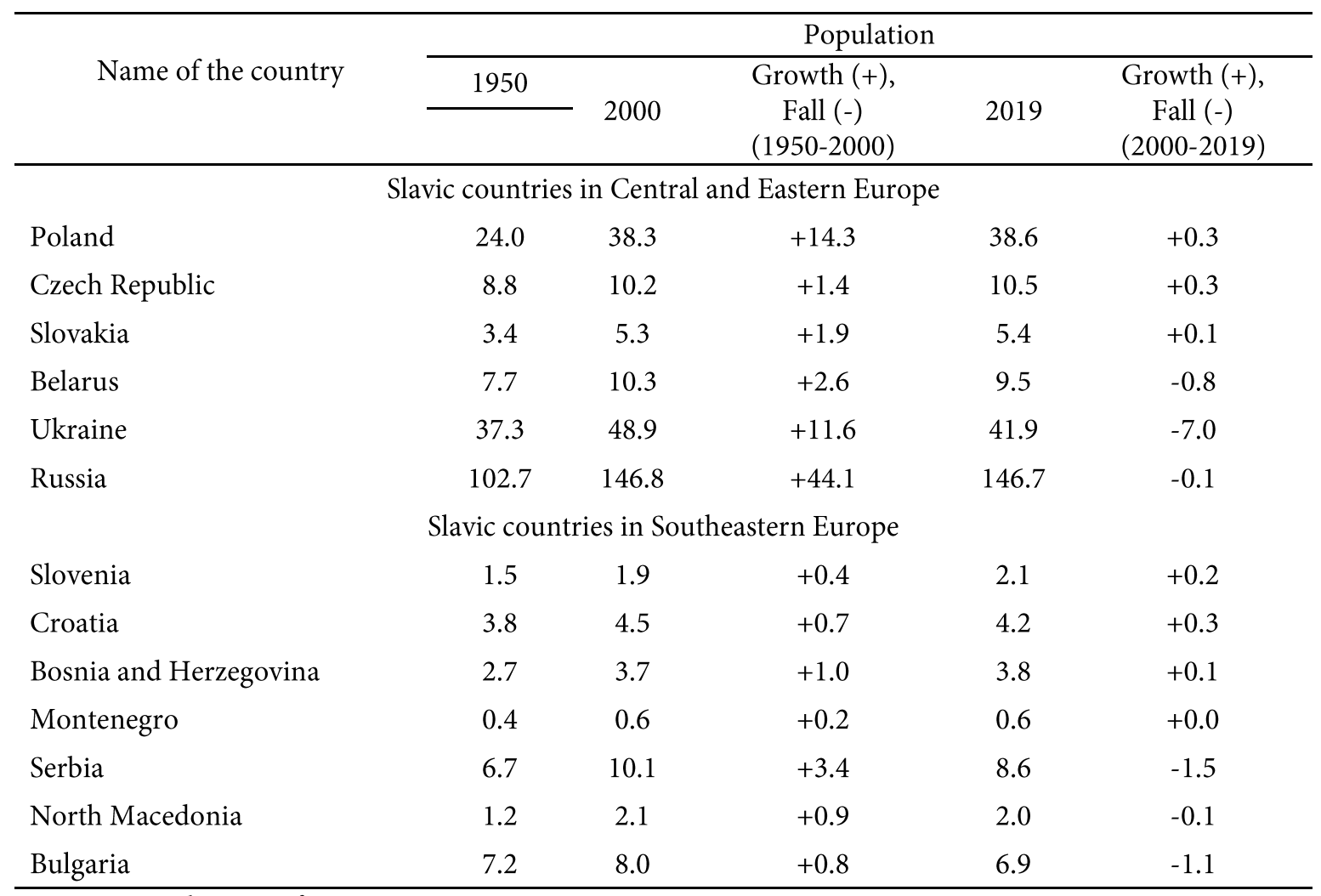

Source: Population Reference Bureau, 2020.

Table 10. Birth and death rate, and general natural increase of Slavic countries, \%o

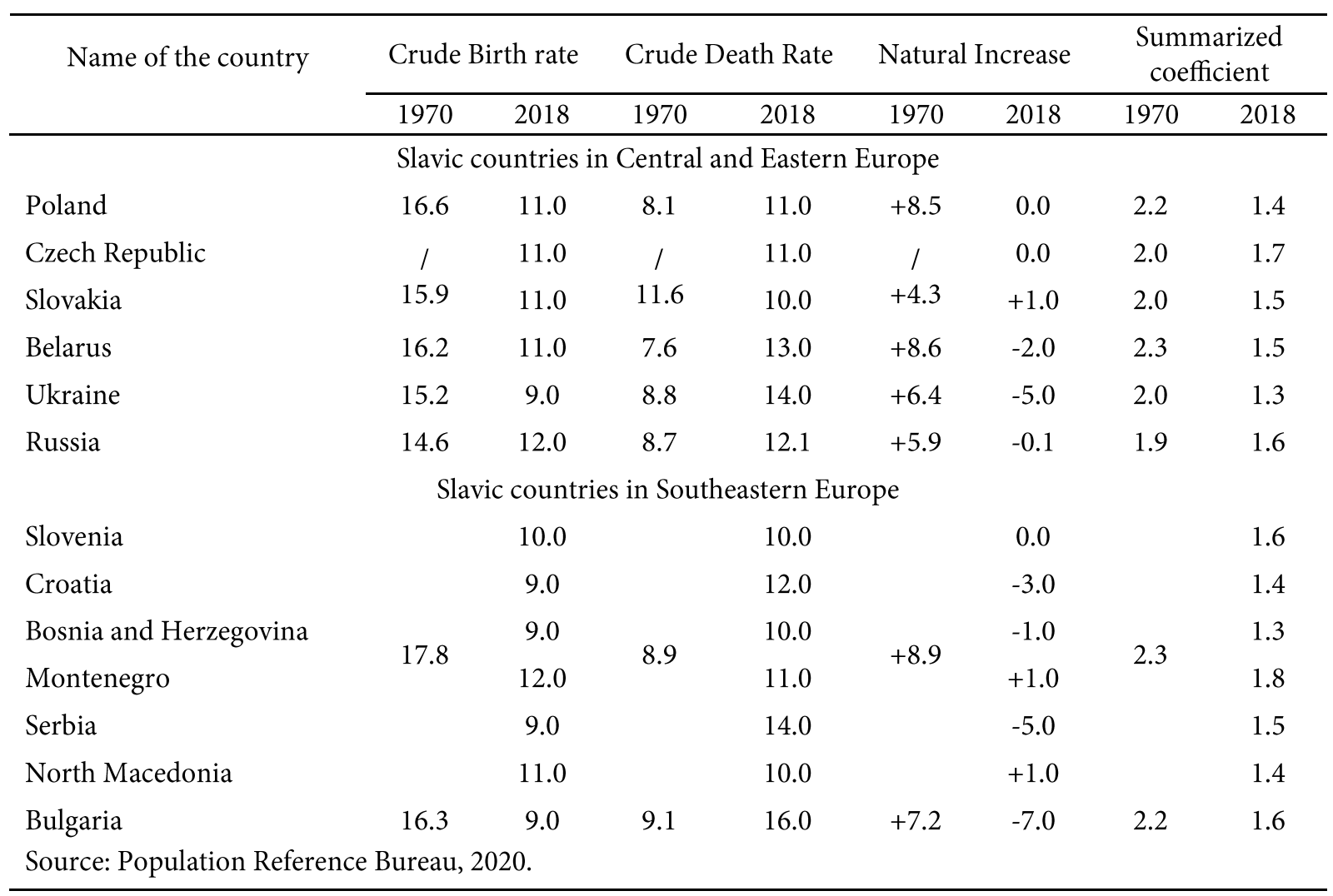


The decline in the population in the Slavic countries of Eastern and Southern Europe is due to the unfavorable demographic situation. As the analysis shows, it deteriorated in the late XX- early XXI centuries. Demographic processes were characterized by low birth rates and fairly high mortality rates, which predetermined the natural decline of the population in many countries of Eastern and Southern Europe. As shown in Table 10, in 2014, the highest birth rate was recorded in Russia, Montenegro and Belarus, while in other countries was at the level of $1-10 \%$. The highest death rates were recorded in Bulgaria, Ukraine and Serbia, while relatively lower death rates were recorded in North Macedonia, Bosnia and Herzegovina, and Slovenia. As a result, high natural population loss was recorded in Bulgaria and Serbia. In Poland, Belarus, and Bosnia and Herzegovina, the natural population decline is low, and country such as the Czech Republic has a balance of birth and death rates.

\section{Conclusion}

The current demographic status quo in Russia is generally characterized by depopulation trends, mainly because of the economic process which started in the 1990-es transition. Nevertheless, the reduced fertility rate is compensated by the migration of population from 10 post-Soviet republics (CIS countries) mostly by economic reasons (Arel, 2002). On the other hand, the adolescent fertility rate in Russia is one of the highest in the Slavic world, which also argues for the improvement of the demographic situation in Russia in the future.

The diverse demographic patterns in former communist Slavic countries show the relevant role of political factors in determining demographic pictures of the countries. In the case of the observed countries, that impact was negative, and the final result of that influence is depopulation. Generally observed, the number of Slavs is in the overall decline in Russia and in Southeastern Europe (the situation among Western Slavs - Poles, Czechs and Slovaks is somewhat different). Persistent migrations, economic underdevelopment and weak industrial indicators, with insufficient care of the state (effective birth control), are one of the main causes of this decline. Most of the Slavic countries shared a similar fate in terms of other demographic tendencies as well: reducing fertility rates, increasing life expectancy and a growing share of the population older than 65 years.

The epochs of the World War I and World War II, then the political collapse of the Soviet Union (1991) the disintegration of Yugoslavia (1991) and peaceful dissolution of Czechoslovakia (1993) brought to economic stagnation and demographic regression, which favor religious and national (ethnic) ambivalence, as well as the strengthening of groups ethnically isolated or religiously differentiated both in Russia and rest of Slavic world. The contemporary challenges of modern society in terms of global politics (terrorism and migrations) and economic transformations will, in particular, be more pronounced and turbulent in Slavic societies.

The threshold for natural reproduction is determined by a coefficient of 2.11. If it is higher than this value, the number of the nation increases, and below it - decreases. The lower threshold of natural reproduction is determined by a coefficient of 1.5, if it is lower - the nation dies out. In 2018, a relatively high crude birth rate of $1.7-1.8$ was recorded in the Czech Republic and Montenegro, while the lowest coefficient - 1.3 - was recorded in Ukraine and Bosnia and Herzegovina. In other countries, it was at the level of 1.6-1.4. In 2018-2020, General and special coefficients that characterize the dynamics of demographic processes did not improve. Depopulation was observed in almost all Slavic countries in Europe. This situation allows the conclusion that in all countries of Central, Eastern and South-Eastern Europe, the Slavic peoples did not reproduce themselves. Therefore, the main problems of the Slavic States of Europe, along with climate change and urbanization, included the problems of the crisis demographic situation.

One of the reasons that hinder the growth of demographic potential is the poverty of the Slavic population. The gross national income per capita, taking into account purchasing power parity, is one of the lowest in Eastern and Southern Europe. In 2017, in the developed countries of the world, it amounted to 43,400 dollars, in the European Union - 41,200, in Southern Europe - 34,400, and in the Eastern Europe - 23,000 dollars. The lowest incomes were recorded in Ukraine (8,900 dollars), Bosnia and Herzegovina $(12,800)$ and Serbia (14.000). Relatively higher income was recorded in the Czech Republic (35,000 dollars.), in Slovenia $(33,900)$ and Slovakia $(31,400)$. In Russia and Croatia, the revenue exceeded 25 thousand dollars per capita, and in other countries it varied from 20 to 18 thousand dollars.

The reasons for the modern problems of the Slavic peoples of Europe, can be formulated as follows: 1) Low income of the population in the Slavic countries of Western and Eastern Europe; 2) The crisis of the ideological and spiritual state of the population (changes in value orientations, late marriages and later birth of children, lack of children, a large number of divorces); 3) Lack of civilization cohesion and identity, and 4) Weak targeted measures of regional state demographic policy. There are solutions for the unfavorable demographic situation. It is necessary to weaken the inertia of demographic processes and increase the level of population reproduction. Also, it is necessary to set and solve a priority difficult task - to reduce the demographic balance to zero in the near future. To do this, it is important to increase the fertility of women in all age groups and ensure an increase in the fertility rate to 1.82.0. In order to maintain the interests of the so - called "natural family" - a stable traditional family represented by a man, woman and their children, certain measures are required. In an era of changing views on the family and devaluation of traditional values, it is necessary to fund the programs to support the ideals of the natural family to a greater extent than other social programs, such as support for sexual minorities, family planning, etc. The idea of supporting a natural (traditional) family can be aimed at improving the quality of people's life, provided that the parity of individual and family rights is observed.

\section{References}

Arel, D. (2002). Demography and Politics in the First Post-Soviet Census: Mistrusted State, Contested Identities. Population, 57(6), 801-827. DOI: 10.3917/popu.206.0791

Bruk, S. I. (1981). Naselenie mira: Etnodemograficheskii spravochnik. Moscow: Nauka.

Creighton, H. (2014). Europe's Ageing Demography. London: International Longevity Centre. 
Eberhardt, P., \& Owsinski, J. (1996). Ethnic Groups and Population Changes in Twentieth Century Eastern Europe: History, Data and Analysis. New York: Routledge.

Ediev, D. (2001). Application of the Demographic Potential Concept to Understanding the Russian Population History and Prospects: 1897-2100. Demographic Research, 4, 289336. http://www.jstor.org/stable/26348028

Goldstone, J. A., Kaufmann, E. P., \& Toft, M. D. (eds) (2012). Political demography: How population changes are reshaping international security and national politics. Oxford: Oxford University Press.

Josipovič, D. (2016). The post-Yugoslav space on a demographic crossway: 25 years after the collapse of Yugoslavia. Stanovništvo, 54(1), 15-40. DOI: 10.2298/STNV160415006J

Leasure, J. W., \& Lewis, R. A. (1967). Internal migration in the USSR: 1897-1926. Demography, 4(2), 479-496. DOI: $10.2307 / 2060294$

Loginova, N. N. (2011). Naselenie Respubliki Mordoviya: geodemograficheskaya situatsiya, dinamika i struktura. Saransk: National Research Mordovia State University.

Lović Obradović, S., Babović, S., \& Shpak, N. (2016). Serbia and Russia on the Demographic Map of Europe Two Decades after the Fall of Communism. Trames, 20(1), 59-73. DOI: 10.3176/tr.2016.1.04

Mazurov, Y., \& Slipenchuk, M. (2016). Historical Heritage of Slavic Peoples as a Field of Academic and Applied Studies. Journal of the Geographical Institute "Jovan Cvijic" SASA, 66(1), 157 -167. DOI: $10.2298 / \mathrm{IJGI} 1601157 \mathrm{M}$
Mazurov, Y. L., \& Vartapetov K. (Eds). (2001). Our Common Heritage of Europe. Proceedings and Report from the Sixth Meeting of Environmental Studies Students. Moscow: Heritage Institute.

Neyer, G., Andersson, G., Kulu, H., Bernardi, L., \& Bühler, C. (eds) (2013). The Demography of Europe. Dordrecht: Springer.

Population Reference Bureau (2020). Statistical Database (electronic source). Retrieved from https://assets.prb.org/pdf19/2019world-population-data-sheet_eng.pdf

Rashin, A. G. (1956). Naselenie Rossii za 100 let (1811-1913 gg.). Moscow: Nauka.

Rau, R., Muszyńska, M. M., \& Vaupel, J. W. (2013). Europe, the Oldest-Old Continent. In G. Neyer, G. Andersson, H. Kulu, L. Bernardi, \& C. Bühler (eds.), The Demography of Europe (pp. 119-137). Dordrecht: Springer.

Rossiyskoy Gazety (2010). ROSSTAT on the results of the allRussian population census in 2010 (internet-portal). Retrieved from http://www.rg.ru/2011/12/16/stat.html

ROSSTAT (2020). Statistical Database (electronic source). Moscow: Russian Federal State Statistic Service (ROSSTAT). Retrieved from http://www.gks.ru

Weber, C., \& Goodman, A. (1981). The Demographic Policy Debate in the USSR. Population and Development Review, 7(2), 279 -295. DOI: $10.2307 / 1972624$

Weiner, M., \& Teitelbaum, M. (eds) (2001). Political Demography, Demographic Engineering. New York: Berghahn Books. 